\title{
Estimation of landfill gas and its renewable energy potential in Lagos, Nigeria
}

\author{
Imoukhuede Moses Idehai $^{1}$ Christopher N. Akujieze ${ }^{1}$
}

Received: 5 February 2015/ Accepted: 13 May 2015/Published online: 10 June 2015

(c) The Author(s) 2015. This article is published with open access at Springerlink.com

\begin{abstract}
Estimation of the landfill gas (LFG) and electricity potential is one of the significant aspects of an integrated landfill development. In view of this, geological surveys were undertaken in all the government operated landfills in Lagos to appraise ground conditions for the exploitation of the anaerobically generated LFG. Thereafter, attempts were made to estimate the electricity potentials based on various equations and models. The geology of the landfill areas is essentially that of the Oligocene to Pleistocene Coastal Plain Sands except for that of Epe landfill area which is of Recent Deposits. The lithologies of the landfills in the Coastal Plain Sands areas seem suitable for landfill gas capture upon capping. Using stoichiometry, an achievable electrical power of 123.75 MW was deduced. By juxtaposition with an established Malaysian scenario, the yearly electrical energy was placed at $646,663.2 \mathrm{MWh}$ with a tariff revenue in excess of US\$64.68 million/year. Furthermore, an accruing carbon credit of about US\$31.73 million/year is expected from certified emission reduction (CER) under the Kyoto Protocol. However, estimations by comparison with gas capturing sites across the globe yielded a mean of $38.35 \mathrm{MW}$. This is about $30 \%$ of the theoretical and is capable of providing electricity to over 230,000 inhabitants. Hinged on actuality, this latter evaluation may aid to eradicate spurious estimations for practical purposes, and is critical in terms of global LFG capture economics. The concomitant benefits of LFG exploitation are expected
\end{abstract}

Imoukhuede Moses Idehai

imoism@gmail.com

1 Department of Geology, University of Benin, Benin City, Nigeria to be exponentially higher in terms of reduction of greenhouse gases and mitigation of environmental hazards.

Keywords Landfill gas - Electrical power - Certified emission reduction (CER) - Lagos

\section{Introduction}

Globally, about 1.5 billion tonnes of methane is produced from landfills every year but only about $10 \%$ of this is captured [1]. Landfill gas is a product of anaerobic biodegradation of refuse in landfills, and it primarily contains methane $\left(\mathrm{CH}_{4}\right)$ and carbon dioxide $\left(\mathrm{CO}_{2}\right)$, with trace amounts of non-methane organic compounds (NMOC) that include air and volatile organic compounds pollutant [2].

The IPCC (2013) Report, asserted with about $95 \%$ certainty that humans are the dominant factor in view of climate change since the 1950 s. Therefore, the ability to capture methane from the Lagos landfills will help to mitigate contributory effects to global warming and its attendant consequences [3].

Various practical data and scholarly estimations of the electricity potentials of landfill gas (LFG) have been forwarded and these can be juxtaposed for estimations in the megacity called Lagos. However, in order to limit observable disparities and ambiguities in these derivations and thus allow for more accurate projections, these estimations can be gauged by comparing theoretical values with those obtained in the field. In terms of LFG capture economics, the latter are far more significant in that they are hinged on available technology and actuality.

Methane is lighter than air and can accumulate beneath structures and buildings, resulting in vegetational stress and toxicity due to $\mathrm{H}_{2} \mathrm{~S}$ and VOCs, corrosion due to $\mathrm{CO}_{2}-$ 
created acidity, greenhouse gases and air emissions. It is explosive above $5-15 \%$ by volume and causes subsurface migration offsite (up to $150 \mathrm{~m}$ ). Nonetheless, attenuative and compacted soils serve as seals and can prevent further migration of landfill gases thereby enhancing their beneficiation potentials. All the landfill areas are underlain by these soils except in Epe.

Lagos which has about $27.4 \%$ of the country's urban population but which has had its electric power allocation plummeting from over $800 \mathrm{MW}$ (of the country's $4000 \mathrm{MW}$ ) in the last decade to below $300 \mathrm{MW}$ in 2011 [4], is in dire need of alternative energy sources. Therefore, the exploitation of the LFG potentials provides veritable options in terms of electricity and environmental benefits. For this to be actualized, proper estimation of the practically derivable electricity is pivotal in the economics of the entire process. Hence, the thrust of this study is to attempt the estimation of the green energy potential of the landfill gas (LFG) in the Lagos area using models and equations devised across the globe. The goal is to project values that are more in harmony with actuality.

\section{Objectives}

Given existing ambiguities and disparities in LFG estimations, the thrust of this study is to evaluate the LFG electricity potential of the Lagos area by comparisons with several theoretical models and field data. The essence is to project values that are more in line with observed field data. This will help to provide relevant agencies across the world with a practicable template to formulate their LFG gas capture projections and economics.

\section{Study area}

The study was undertaken in all the government-operated landfill areas in Lagos (Fig. 1). The Lagos Waste Management Authority (LAWMA) is the Government Agency that is statutorily charged with Solid Waste Management in Lagos State. It is saddled with the responsibility of collecting, transporting and general handling of all the solid waste generated from different sources within Lagos. Given its associated successes in the current political dispensation, the LAWMA's model is being replicated in such places as Federal Capital territory (Abuja) Ogun State, Plateau State, Ekiti State, Cross Rivers State, Osun State, Banjul (Gambia), Accra Metropolitan Authority (Ghana), City of Freetown (Sierra Leone), Addis Ababa (Ethiopia).

Lagos State lies approximately between longitudes $2^{\circ} 42^{\prime}-3^{\circ} 42^{\prime}$ East and latitudes $6^{\circ} 22^{\prime}-6^{\circ} 52^{\prime}$ North. The southern boundary of the state lies along the Atlantic coastline while its northern and eastern boundaries are shared with Ogun State. The western boundary is bordered by the Republic of Benin. Its size is about $3577 \mathrm{~km}^{2}$, has about $180 \mathrm{~km}$ Coastline and is about $4.6 \mathrm{~m}$ above sea level (ASL). It has about $22 \%$ water coverage consisting of rivers, lagoons, creeks and streams [4] with 20 LGAs and 37 LCDAs and over 2600 communities. In 2006, the National Population Commission (NPC) recorded a population of 9,013,534 with an annual growth rate of $3.2 \%$. However, according to the report of UN (1992), Lagos has a geographical area that is $0.39 \%$ of Nigeria's $923,773 \mathrm{~km}^{2}$ and a population estimate of 16.86 million (27.4\% of Country Urban). The projected population was 20.19 million (2010) and 24.5 million (2015) in the said report. Lagos is the most populous city in Nigeria, the second fastest growing city in Africa and the seventh fastest growing city in the world. Corollary, in this work, the population is estimated at 21 million.

\section{Geological settings}

The geology of the landfill areas is essentially that of the Oligocene to Pleistocene Benin Formation (Coastal Plain Sands) except for that of Epe landfill area which is of Holocene (Recent Littoral and Lagoonal) Deposit (Fig. 2). The name Coastal Plains Sands, now called Benin Formation, was introduced by Tattam [5] to describe the extensive red earths and loose, ill-sorted sands underlying the Recent Deposits of the Niger Delta and overlying the (PlioceneEocene) Tertiary Sedimentary Group. The name Benin Formation is now well-established in the stratigraphy of the Delta and it has been retained in the Southern Nigeria Sedimentary Basin, although the abundance of clays in the Formation in this area does not make it entirely appropriate [6]. They are indistinguishable in the field from the TertiaryCretaceous sediments, mainly much of the Ilaro Formation and the basal continental beds of the Abeokuta Formation.

\section{Antecedent and assessments of the landfills}

The geology of the Olusosun area is generally characterized by Coastal Plain Sands. It forms low lying, gently sloping topography with extensive red earths and loose poorly sorted sands that are mixed with an abundance of clays. Thicknesses of over $15 \mathrm{~m}$ of clayey/lateritic soils were observed in several locales within the landfill. The elevation generally ranges from 18 to $52 \mathrm{~m}$ above the mean sea level.

It was officially opened for use as a landfill on the 19th of November, 1992. Unlike the other landfills which only operates during the day ( $7 \mathrm{am}-7 \mathrm{pm}, 7$ days a week), the Olusosun landfill operates for all $24 \mathrm{~h}$ of the day and 

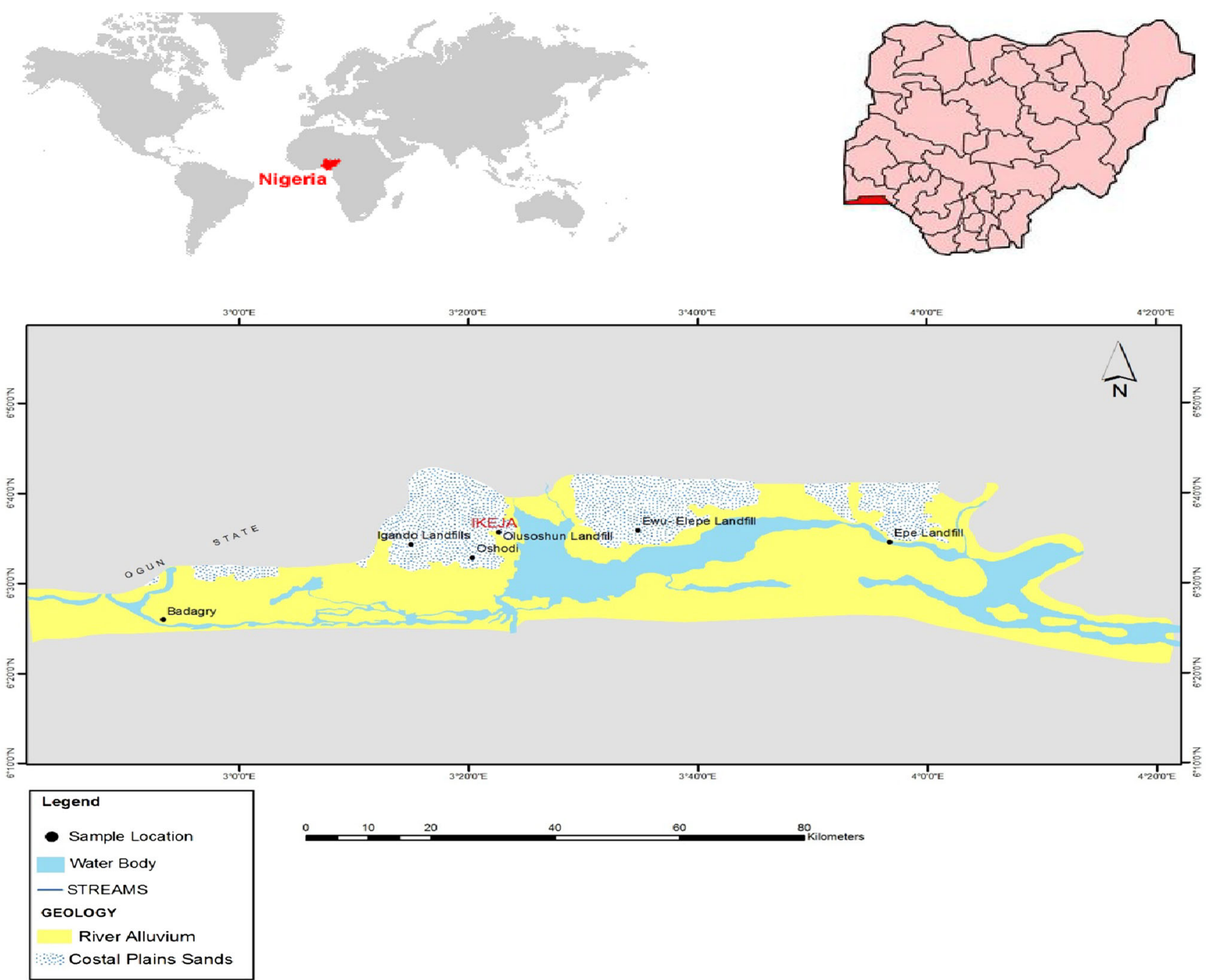

Fig. 1 Map of the geology of lagos state showing the landfill locations and other areas (inset world map showing Nigeria and map of Nigeria showing Lagos State)

everyday of the year. It occupies an area of about 42 hectares. It is by far the busiest landfill in Lagos and receives about $54 \%$ of the state's MSW. The site had been used in the past as a burrow pit where sand was mined for the Lagos-Ibadan road construction. Initial excavation depth of 7-12 m existed before tipping of waste commenced. The landfill was designed to receive $7,365,000$ tonnes of solid waste during its operational lifespan of 10 years. This figure represents a yearly average tipping volume of 736,500 tonnes. Operational design of waste to cover ratio of 9:1 was chosen for the 10 years duration [7].

The writers suggest that the landfill is still able to receive MSW based on a number of factors. Firstly, it is possible that before the renaissance of LAWMA, and considering losses by decomposition, compaction and recycling, only about half of the projected 736,500 tonnes/ year were emplaced before 2008 (amounting to a total MSW in place of 5,523,750 tonnes in the intervening
15 years). Also, the current depth in parts hovers around $15 \mathrm{~m}$. Settlement, overlying pressure of the waste and further compaction by machines, may also have increased the density of the deposited waste streams with time. Bhide [8] estimated a MSW density of $800 \mathrm{~kg} / \mathrm{m}^{3}$ after dumping. Given the plethora of factors, it is plausible to arrive at a density of about $2200 \mathrm{~kg} / \mathrm{m}^{3}$ bringing the capacity of the landfill to $13,860,000$ tonnes. The Olusosun currently receives about 1,700,000 tonnes/year of MSW. Given that the quantity of soil added periodically is marginal and discounting for recycling and decomposition, only about $60 \%$ of these may be emplaced in the landfill. In addition, the operators of the landfill are at liberty to marginally extend the elevation of the sites to accommodate more wastes provided proper capping is done and other sanitary conditions met. Therefore, it is possible for the Olusosun landfill operations to subsist for upward of another ten years. 


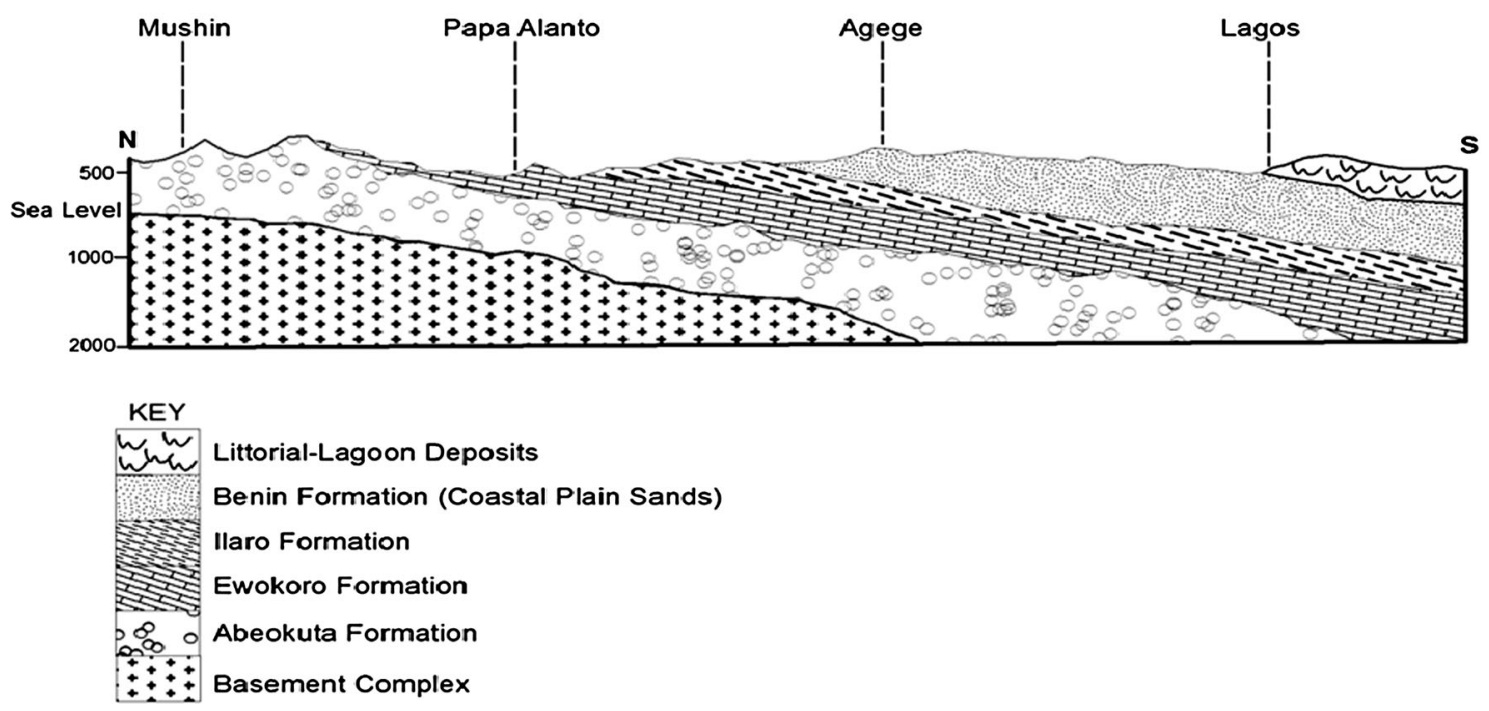

Fig. $2 \mathrm{~N}-\mathrm{S}$ geological section Showing the major geological formations in the Lagos area [6]

The geology of the Soluos 1-3 areas is the same as that of Olusosun. It consists of inter-bedded sands, gravelly sands, silts and clays. Portions of thicknesses of over $13 \mathrm{~m}$ of clayey/lateritic lithology are evident within the landfills. These study areas (Soluos 1 having been closed previously) are situated in Igando town within Alimosho LGA of Lagos. The locations are approximately between latitude $6^{\circ} 31^{\prime} 0^{\prime \prime} \mathrm{N}-$ $6^{\circ} 31^{\prime} 30^{\prime \prime} \mathrm{N}$ and longitude $3^{\circ} 15^{\prime} 0^{\prime \prime} \mathrm{E}-3^{\circ} 15^{\prime} 30^{\prime \prime} \mathrm{E}$. River Owo demarcates the area from Ado-Odo/Ota LG of Ogun State. The soil is composed of red and sandy-clay (laterite). The vegetation is composed of swamp forest and coastal plants. The hydrology is dominated by River Owo and its tributaries (River Abesan, River Oponu and River Illo). They drain into the Ologe Lagoon. Soluos 2 with an area of about 7.8 hectares and with an average current depth about $12 \mathrm{~m}$ was opened for operation on the 20th of July 2006. Soluos 3 is about $1 \mathrm{~km}$ from Soluos 2. It has an area of 5 hectares with a depth of about $13 \mathrm{~m}$ and was opened on the 4th of July, 2008. The hydrogeological condition of the landfill site is consistent with the regional hydrogeological setting of Lagos area [9]. The subsurface geology of the landfill consists of clay intercalated with lateritic clay which is capable of serving as a landfill gas seal.

The Epe landfill was opened on the 12th of February, 2009. It is the largest landfill by size with an area of about 80 hectares (of which 72 hectares rest on the flood plain adjoining the Epe-Lekki Lagoon and 8 hectares is forested land). However, it is the quietest with only about $4 \%$ of the Lagos MSW receipt.

The location is about $5 \mathrm{~km}$ on the outskirt of Epe town, along Ibeju/Lekki-Epe Expressway and about $1 \mathrm{~km}$ from the Epe Lagoon. The geology is that of Recent Littoral/ Lagoonal Deposit consisting mainly of sands and silts. The topsoil exhibits a light greyish colouration and is underlain by reddish-coloured sand and silts which gives the impression of being clayey from a distance. The site is sequestered away from the town and is almost completely surrounded by trees which have the ability to trap ensuing $\mathrm{CO}_{2}$. The intention is to develop this site to an integrated landfill. However, the soils which are essentially sandy are incapable of retaining landfill gases in an enclosure.

Coastal Plain Sands underlies Ewu-Elepe. Ewu-Elepe is a suburb of Ikorodu in Lagos. It is semi-urban. Like Olusosun and Soluos $1-3$, it was established upon erstwhile burrow pits. The landfill slopes towards a floodplain that drains into River Ijede. Farming activities subsist within the plains and other areas. The Ewu-Elepe landfill was opened on the 14th of November, 2008 and receives about $7 \%$ by weight of the MSW in Lagos. The area is underlain by competent attenuative clayey and red lateritic soils.

\section{Overview of electricity in Nigeria}

The Nigerian power sector was started in 1962 as Electricity Corporation of Nigeria (ECN). Niger Dam Authority (NDA) was created later to harness the country's hydropower resources. The name of the power sector was changed to National Electric Power Authority (NEPA) after the merger of NDA and ECN in 1972. Operating under the name of NEPA, the power sector was granted the monopoly of generation, transmission and distribution of electric power in the country. As a result of general poor performance indices of NEPA, a major reform in the sector known as Electric Power Sector Reform (EPSR) Act was carried out in 2005. The foremost objective of the reform was to liberate the marketing policy in the sector by breaking the long-time monopoly being enjoyed by the 
NEPA. The reform led to the establishment of a statutory regulatory commission, Nigerian Electricity Regulatory Commission (NERC) entrusted with the mandate to monitor all power generation, transmission and distributionrelated activities in the nation's power sector. Independent Power Producer (IPP) participation was supported as part of the reform measures. The reform also endeavours to segregate the entire power system operations into three independent companies comprising six generation, one transmission and eleven distribution companies implemented in 2007 [4]. The collection of these independent companies is now called Power Holding Company of Nigeria (PHCN). The reforms are yet to bring significant changes to the situation in the energy sector of the country. The latest final privatization processes of 2013 are ostensibly geared at revamping the power sector.

According to the US Department of Energy (DOE), total installed electricity capacity in Nigeria was 5900 Megawatts in 2004. Total electricity generation during 2004 was 19 million Megawatt-hours. However, the Nigerian electric power sector operates well below its estimated capacity, and power outages occur frequently. Consequently, only about $40 \%$ of Nigerian populace has access to grid electricity supply, which is generally unreliable. All sectors (residential, commercial and industrial) are increasingly in the habit of using privately operated generators to supply electricity occasioned by frequent power outages. In addition, the demand for electricity continues to increase as the population and economy grow. Nigeria's electricity consumption is projected to increase to about 15,000 MW in 2025 [10].

In most recent years, power peaked at $4517 \mathrm{MW}$ (21 December 2012 and dropped to 3443 MW in April, 2013 [11]. The exploitation of the vast landfill gas potentials for electricity generation is therefore recommended in view of the huge concomitant benefits.

\section{Steps in LFG production}

Waste in landfill decomposes anaerobically to produce LFG. About $50 \%$ of LFG is methane. This is collected using an underground collection of pipes and wells. From this, the gas is drawn to a renewable energy facility compression system. Here, it is dewatered, pressurized and filtered to make it clear.

The filter removes any large piece of debris and liquid that may have become mixed with the gas. Then it enters a compressor. This raises the pressure until it is high enough for the gas to be used as a fuel. During compression, the temperature of the gas rises and must be cooled down by an after-cooler. Inside the after-cooler, the temperature of the gas is lowered and this allows for any remaining moisture to be condensed. The gas is then filtered a second time to remove condensed moisture. At this stage, the gas is reheated to prevent any further condensation and is thus ready to be used as a renewable energy fuel. All these processes take seconds.

Engine or turbine can be used to generate electricity. An engine that runs on landfill gas is not too different from a car engine. It is equipped with pistons, air filter, exhaust, radiator and car battery. LFG enters the engine and is combusted causing the pistons to spin a drive shaft. Pistons convert chemical energy to heat energy caused by fuel combustion and then into mechanical energy that turns a drive shaft. The drive shaft/crank shaft is connected to a generator which converts the mechanical energy into electricity [12].

\section{Estimation of LFG potentials: methodology, results and discussion}

A synopsis of the quantification of the municipal solid wastes (MSW) in Lagos for some years is given in Table 1. For estimation of the LFG potentials, it was also essential to characterize the wastes. This is because only the organic-related matter is significant for anaerobic degradation and conversion to LFG. The characterization here applied for the Lagos MSW is as reported by Lagos Waste Management Authority, LAWMA and other workers (Fig. 3). Parts of the Olusosun landfill and its inchoate gas capturing scheme are illustrated in Fig. 4. The principles of methane generation as given by several equations and renowned models were applied herein to estimate the derivable electrical energy and the accruing revenues in the Lagos scenario. These numbers of models were explored in order to present a robust overview of possible estimations.
Table 1 Quantification (in tonnes) of MSW to Landfills in Lagos [13]

\begin{tabular}{lllllrl}
\hline & Olusosun & Soluos 2 & Soluos 3 & Ewu-Elepe & Epe & Total \\
\hline 2007 & $1,078,766$ & $617,657.5$ & $526,321.5$ & & & $2,222,745.50$ \\
2008 & $1,425,138$ & $688,617.9$ & $700,787.0$ & & & $2,814,543.45$ \\
2009 & $1,973,427$ & 655,265 & 757,043 & 287,015 & 158,958 & $3,831,708$ \\
2010 & $1,466,843$ & 422,349 & 391,436 & 191,512 & 77,453 & $2,549,629$ \\
\hline
\end{tabular}


Each model considers some key factors in LFG production/exploitation. However, as may be later evident, none of the theoretical model integrates all the components essential for LFG electricity evaluation. Hence, the associated disparities and seeming ambiguities in derived figures and the need for correlation with field data. Nonetheless, the values devised from them can also be used to make reasonable field projections.

The following are various postulations used for the estimations of the landfill gas potential in the Lagos area.

\section{Model 1 (after Suberu et al. 2012... Malaysia [4])}

Suberu et al. [4] used a simplistic zero order equation to estimate the LFG electricity potential of Lagos. This equation only considers the mass of the MSW and its assumed calorific value. The equation is again applied here with more evaluation of recent data.

Preamble:

Population of Lagos $=21,000,000[14]$

Generation per capital $(\mathrm{GPC})=0.63 \mathrm{~kg} /$ day

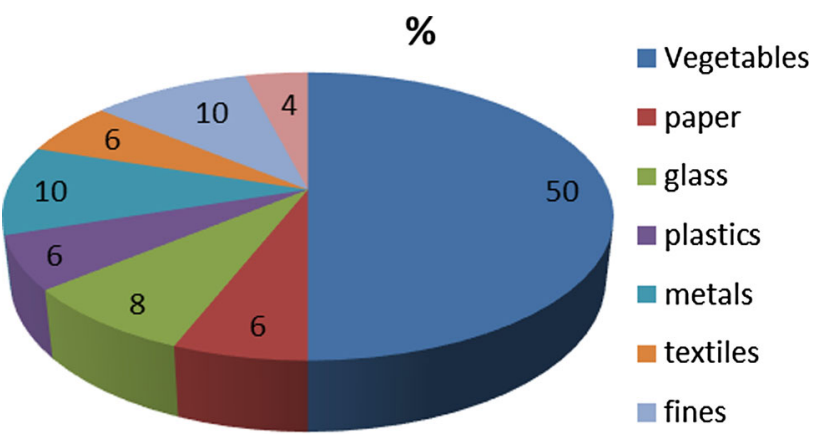

Fig. 3 Characterization of the Lagos waste by weight [11]
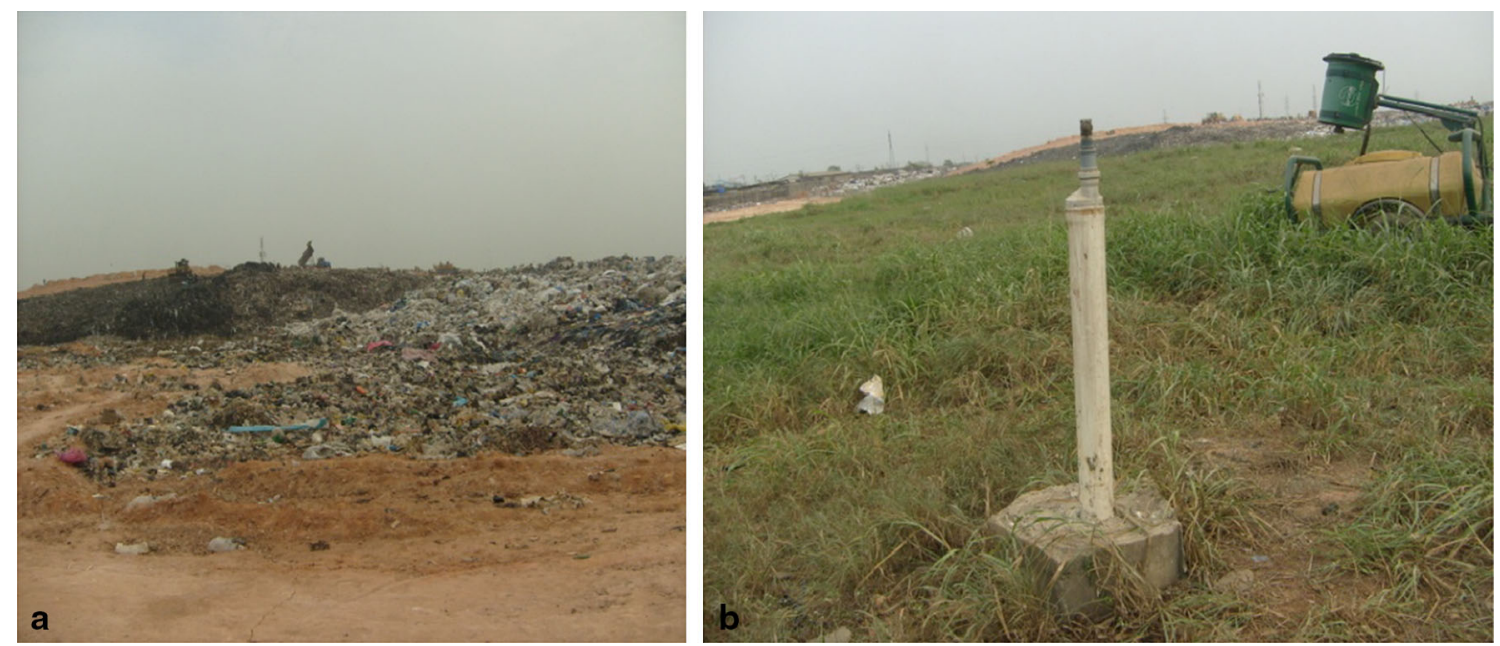

Fig. 4 Portions of the Olusosun landfill (a partially capped areas; $\mathbf{b}$ a well-head for LFG capture)
MSW generated per day $=13,230$ tonnes

$70 \%$ of (1) makes it to the landfill

$=9261$ tonnes/day

$=3.38$ million tonnes of waste per year

This compares well with the reported average MSW collection by LAWMA for years 2008-2009 of 3.32 million tonnes (Table 1).

(Note that $60 \%$ of (2) is the organic fraction of the MSW).

Therefore,

Waste $=9261$ tonnes $/$ day

In this model, the power and energy potential can be estimated as follows:

$E_{\mathrm{p}}=\mathrm{HV} \times W \times 0.0011628$

$P_{\mathrm{gp}}=E_{\mathrm{p}} / 24$

where $E_{\mathrm{p}}$ energy potential $(\mathrm{kWh}), P_{\mathrm{gp}}$ power generation potential $(\mathrm{kW}), \mathrm{HV}$ calorific value of the waste $(\mathrm{kcal} / \mathrm{kg})$, $W$ weight of the waste $(\mathrm{kg})$.

Calorific value (Higher heating value) used for the purpose of this calculation $=905 \mathrm{kcal} / \mathrm{kg}$.

Substituting,

$E_{p}=905 \times 9261 \times 0.0011628=9745.7 \mathrm{MWh}$

$P_{\mathrm{gp}}=406.1 \mathrm{MW} *$.

If generators of $30 \%$ efficiency are installed, the amount of actual electricity (or electrical power) that would be generated is

$\operatorname{Power}(P)=0.3 P_{\mathrm{gp}}$

$P=121.83 \mathrm{MW}$. 


\section{Breakdown:}

Olusosun (i.e. 0.54 MSW $\rightarrow 0.54$ electrical power) $=65.8 \mathrm{MW}$

Soluos 2(0.17 MSW $)=20.7 \mathrm{MW}$

Soluos 3(0.18 MSW $)=21.9 \mathrm{MW}$

Ewu- Elepe $(0.07 \mathrm{MSW})=8.5 \mathrm{MW}$.

(*It is instructive to note that Suberu et al. [4] estimated $P_{\mathrm{gp}}$ of $483 \mathrm{MW}$ from a Lagos population of about 17.55 million people (2008). Consequently, an $E_{\mathrm{p}}$ of 13,226 MWh and $P_{\mathrm{gp}}$ of $551 \mathrm{MW}$ and electricity of $165.3 \mathrm{MW}$ would be currently derivable. The plausibility of this scenario does not seem supported by available data).

\section{Model 2 (after Taherzadeh 2010: Sweden [15])}

Taherzadeh posited that the MSW of 150,000,000 inhabitants can be converted to about 1000-5000 MW electricity, depending on the technology used. The lower value is here considered because the LFG generation process in Lagos is entirely by anaerobic degradation. Thus,

$150,000,000 \rightarrow 1000 \mathrm{MW}$ (lower limit)

$\therefore 1,000,000 \rightarrow 6.7 \mathrm{MW}$

Estimated population of Lagos $=21,000,000$

About $70 \%$ of MSW is landfilled

$\rightarrow 14,700,000$ people $\rightarrow 9261$ tonnes/day MSW

From (11),

$14,700,000 \rightarrow 98 \mathrm{MW}$ (lower limit)

$14,700,000 \rightarrow 490 \mathrm{MW}$ (upper limit)

Using methane emission estimation, he averred that,

A population of $100,000 \rightarrow 500 \mathrm{~m}^{3} / \mathrm{h}$ of landfill gas (LFG)

Hence,

$1,000,000 \rightarrow 5000 \mathrm{~m}^{3} / \mathrm{h}$

Adopting this in the Lagos estimations,

$14,700,000 \rightarrow 9261$ tonnes MSW

$$
\rightarrow 73,500 \mathrm{~m}^{3} / \mathrm{h} \text { of } \mathrm{LFG}
$$

Assuming methane is $50 \%$ of the LFG then,

$$
\begin{aligned}
14,700,000 & \rightarrow 9261 \text { tonnes MSW } \\
& \rightarrow 36,750 \mathrm{~m}^{3} / \mathrm{h} \text { of } \mathrm{CH}_{4}
\end{aligned}
$$

Given:

$$
\begin{aligned}
& 225 \mathrm{~m}^{3} / \mathrm{h} \text { of } \mathrm{CH}_{4} \rightarrow 2.25 \mathrm{MW} \text { of } P_{\mathrm{gp}} \\
& 1 \mathrm{~m}^{3} / \mathrm{hr} \text { of } \mathrm{CH}_{4} \rightarrow 0.01 \mathrm{MW} \text { of } P_{\mathrm{gp}}
\end{aligned}
$$

$\therefore$ From (15),

$36,750 \mathrm{~m}^{3} / \mathrm{h}$ of $\mathrm{CH}_{4} \rightarrow 367.5 \mathrm{MW}$ of $P_{\mathrm{gp}}$

From (9): Electrical power $=0.3 E_{\mathrm{p}}$ (i.e. if efficiency of the engine is $30 \%$ )

Electricity power $=110.25 \mathrm{MW}$

Breakdown:

Olusosun $(0.54 \mathrm{MSW} \rightarrow 0.54$ electrical power $)$

$$
=59.5 \mathrm{MW}
$$

Soluos 2(0.17 MSW $)=18.7 \mathrm{MW}$

Soluos $3(0.18 \mathrm{MSW})=19.8 \mathrm{MW}$

Ewu- Elepe $(0.07 \mathrm{MSW})=7.7 \mathrm{MW}$.

\section{Model 3 (after Surroop and Moheel 2011: Mauritius [16])}

This model is derived from an equation that considers such properties as the density and the lower heating value of generated methane, and the flow rate and gas engine efficiency. The obtained field values in Mauritius were used to estimate for the Lagos area based on waste mass, and by application of standard gas laws.

Given: 1 tonne of MSW

$$
\rightarrow 119.8 \mathrm{~m}^{3} \mathrm{LFG}\left(\text { of } 49 \% \mathrm{CH}_{4}\right)-\text { Mauritius }
$$

$\therefore$ in Lagos, 1 tonne of MSW

$$
\rightarrow 122.24 \mathrm{~m}^{3} \mathrm{LFG} \text { ( of } 50 \% \mathrm{CH}_{4} \text { ) }
$$

1 tonne of $\mathrm{MSW} \rightarrow 61.12 \mathrm{~m}^{3} \mathrm{CH}_{4}$

Correlating (2) with (21) for the Lagos area, 9261 tonne of $\mathrm{MSW} \rightarrow 566,032.32 \mathrm{~m}^{3} \mathrm{CH}_{4}$

(Note that this is the estimate of volumetric flow per day of methane). Also,

9261 tonne of $\mathrm{MSW} \rightarrow 23,584.68 \mathrm{~m}^{3} / \mathrm{h} \mathrm{CH}_{4}$

A comparison of (23) of Surroop Model with (15) of Taherzadeh Model gives

[from (23)] 9261 tonnes $\mathrm{MSW} \rightarrow 47,169 \mathrm{~m}^{3} / \mathrm{h} \mathrm{CH}_{4}$ [from (15)] 9261 tonnes $\mathrm{MSW} \rightarrow 36,750 \mathrm{~m}^{3} / \mathrm{h}$ of $\mathrm{CH}_{4}$

The amount of electricity can be computed using the equation:

$E=M_{\mathrm{CH} 4} \times \mathrm{LHV}_{\mathrm{CH} 4} \times D \times R \times \eta$,

where $E$ electricity or electrical energy in Joules, $M_{\mathrm{CH} 4}$ flow rate of methane $\left(\mathrm{m}^{3} /\right.$ day).

Given $\mathrm{LHV}_{\mathrm{CH} 4}$ lower heating value of methane $\mathrm{J} / \mathrm{kg}=37.5 \times 10^{6} \mathrm{~J} / \mathrm{kg}, \quad D$ density of methane at 
$25{ }^{\circ} \mathrm{C}=0.656 \mathrm{~kg} / \mathrm{m}^{3}, \quad R$ recovery rate of methane $=$

$75 \%, \eta$ efficiency of gas engine $=30 \%$.

From (22),

$M_{\mathrm{CH} 4}=566,032.32 \mathrm{~m}^{3} /$ day.

Substituting values:

$E=3.13295 \times 10^{12} \mathrm{~J}$

But

$1 \mathrm{~J}=1 \mathrm{Ws}=(1 / 3600) \mathrm{Wh}=2.778 \times 10^{-4} \mathrm{Wh}$

$\therefore E=0.87035 \mathrm{GWh}$

Recall: Power $(P)=$ Energy $/$ time

$$
\therefore P=36.265 \mathrm{MW}
$$

Summarily:

9261 tonnes $\mathrm{MSW} \rightarrow 47,169 \mathrm{~m}^{3} / \mathrm{h} \mathrm{CH}_{4} \rightarrow 36.265 \mathrm{MW}$

$566,032.32 \mathrm{~m}^{3} /$ day $\mathrm{CH}_{4} \rightarrow 47,169 \mathrm{~m}^{3} / \mathrm{h} \mathrm{CH}_{4}$

$$
\rightarrow 36.265 \mathrm{MW} \text {. }
$$

\section{Model 4a: (after Johari et al. 2012, Malaysia [17])}

Unlike in previous models where the entire mass of the MSW was considered, this model has stoichiometry as a critical component and considers the biomass. The biomass is the actual methane yielding component of a MSW. Based on the percentage of biomass, the estimated value in Malaysia was correlated for evaluation in this study area. This is how it works.

Johari et al. 2012 estimated that in Malaysia

8,196,000 MSW (of 61.17\% biomass)

$\rightarrow 310,220$ tonnes of methane.

Hence,

I tonne of MSW with $61.17 \%$ biomass

$\rightarrow 0.03785$ tonnes of $\mathrm{CH}_{4}$.

Thus in Lagos,

I tonne of MSW with $60 \%$ biomass

$\rightarrow 0.03126$ tonnes of $\mathrm{CH}_{4}$

$\therefore 9261$ tonnes of MSW of $60 \%$ biomass

$\rightarrow 289.5$ tonnes of $\mathrm{CH}_{4}$.

Therefore, in a year in Lagos,

3,380,000 tonnes of $\mathrm{MSW} \rightarrow 105,667.5$ tonnes ofCH$_{4}$

From (26), in Malaysia (in 2010),
310,220 tonnes $\mathrm{CH}_{4} \rightarrow 1.9$ million MWh

i.e. in a day,

849.92 tonnes $\mathrm{CH}_{4} \rightarrow 5205.5$ MWh of $E$

849.92 tonnes $\mathrm{CH}_{4} \rightarrow 216.9 \mathrm{MW}$ of $P$

$\therefore 1$ tonne $\mathrm{CH}_{4} \rightarrow 0.255 \mathrm{MW}$ of $P$.

Similarly, from (28) and (33a), daily in Lagos

289.5 tonnes $\mathrm{CH}_{4} \rightarrow 73.82 \mathrm{MW}$ of $\mathrm{P}$.

Note that the electrical power in (33a) is actual and based on an internal combustion engine of about $30 \%$ efficiency. Thus,

289.5 tonnes $\mathrm{CH}_{4} \rightarrow 246.07$ of $P_{\mathrm{gp}} \rightarrow 73.82 \mathrm{MW}$ of $P$.

Breakdown:

Olusosun $=39.86 \mathrm{MW}$

Soluos $2=12.55 \mathrm{MW}$

Soluos $3=13.29 \mathrm{MW}$

Ewu-Elepe $=5.17 \mathrm{MW}$

From (33c),

In one day,

289.5 tonnes $\mathrm{CH}_{4} \rightarrow 73.82 \mathrm{MW}$ of electrical power.

Therefore in one year,

105,667.5 tonnes $\mathrm{CH}_{4} \rightarrow 26,944.3 \mathrm{MW}$ of electrical power

Recall: Energy $=$ power $\times$ time.

Thus,

26,944.3 MW of electrical power

$\rightarrow 646,663.2 \mathrm{MWh}$ of electrical energy.

From (30),

In Malaysia (2010),

8,196,000 MSW $\rightarrow 310,220$ tonnes $\mathrm{CH}_{4}$ $\rightarrow 1.9$ million MWh.

Therefore, the estimated Electricity for Lagos in 2013 through LFG is:

3,380,000 tonnes $\mathrm{MSW} \rightarrow 105,667.5$ tonnes $\mathrm{CH}_{4}$ $\rightarrow 0.6466632$ million MWh.

Estimated derivable revenue

(i) Electricity revenue:

Given: In Malaysia 1.9 million MWh was worth US\$190,000,000 
$1 \mathrm{KWh}=\mathrm{US} \$ 0.1$

Assuming US\$1 $\rightarrow$ N156,

$1 \mathrm{KWh} \rightarrow \mathrm{N} 15.60$.

At year 2013 tariff, for domestic electricity,

$1 \mathrm{KWh} \rightarrow \mathrm{N} 11.37$

[The price regime in (39) is the lowest of the commercial tariffs in Nigeria; therefore (38) will be employed for computations].

From (36),

Cumulatively, in a year in Lagos,

26,944.3 MW of electrical power

$\rightarrow 646,663.2 \mathrm{MWh}$ of electrical energy

$\rightarrow 646,663,200 \mathrm{KWh}$.

Combining (38) and (40),

646,663,200 KWh $\rightarrow$ N10.09 billion

$\rightarrow$ US $\$ 64.68$ million

However, combining (39) and (40),

$646,663,200 \mathrm{KWh} \rightarrow \mathrm{N} 7.48$ billion $\rightarrow$ US $\$ 47.95$ million.

(ii) Carbon credit (from certified emission reduction CER).

From (29),

3,380,000 tonnes of MSW $\rightarrow 105,667.5$ tonnes ofCH$_{4}$.

The greenhouse warming potential (GWP) of $\mathrm{CH}_{4}$ is 23 times that of $\mathrm{CO}_{2}$ (IPCC, Third Assessment Report TAR, 2001). Thus,

$105,667.5$ tonnes of $\mathrm{CH}_{4} \rightarrow 2,430,352.5$ tonnes of $\mathrm{CO}_{2}$

[Note that from (43), the carbon equivalent can also be computed given that $\mathrm{C}=12$ and $\mathrm{O}_{2}=16 \times 2=32$. Molar weight $(\mathrm{MW})$ of $\mathrm{CO}_{2}=44 \mathrm{~g}$. Hence, fraction of carbon in $\left.\mathrm{CO}_{2}=12 / 44\right]$. Consequently,

$$
\begin{aligned}
\text { 105,667.5 tonnes } \mathrm{CH}_{4} & \rightarrow 2,430,352.5 \text { tonnes } \mathrm{CO}_{2} \\
& \rightarrow 662,823.41 \text { tonnes } \mathrm{C}
\end{aligned}
$$

1 tonne $\mathrm{CH}_{4} \rightarrow 23$ tonnes $\mathrm{CO}_{2} \rightarrow 6.27$ tonnes $\mathrm{C}$.

Given:

Malaysia (2010): a reduction of $6,514,620$ tonnes of $\mathrm{CO}_{2}$ was estimated to generate a carbon credit of US $\$ 85,000,000$ (approximately US $\$ 13.0476 /$ tonne of $\mathrm{CO}_{2}$ )

$6,514,620$ tonnes of $\mathrm{CO}_{2} \rightarrow \mathrm{N} 13,260,000,000$

1 tonne of $\mathrm{CO}_{2} \rightarrow \mathrm{N} 2035.42$ of carbon credit.

Inputting (43) into (45b),
2,430,352.5 tonnes $\mathrm{CO}_{2} \rightarrow \mathrm{N} 4: 95$ billion

$$
=\mathrm{US} \$ 31: 73 \text { million }
$$

Estimated derivable revenue (total): adding (41) and (46)

$=\mathrm{N} 15: 04$ billion $=\mathrm{US} \$ 96: 41$ million.

\section{Model 4b: IPCC equation derived}

In this Zero-Order Model, biogas generated from landfills is considered fairly steady against time. On this basis, waste age and waste type has no effect on gas production. Several studies have been done to estimate methane production out of municipal landfills. These are mostly based on Monod first-order decay equations which are called first-order decay models. First-order models have a linear relation with maximum potential of methane production per weight unit of waste as well as an exponential relation with decay rate and time. A few models are classified as zero-order models in which methane production is assumed to be fairly constant against time [18].

Based on the Intergovernmental Panel on Climate Change methodology [19], methane emission from landfill was estimated using the following equation:

$$
\begin{aligned}
\mathrm{CH}_{4} \text { emissions (tonne/s) }= & \mathrm{MSW}_{T} \times \mathrm{MSW}_{F} \times \mathrm{MCF} \\
& \times \mathrm{DOC} \times \mathrm{DOC}_{F} \times F \\
& \times 16 / 12
\end{aligned}
$$

where $\mathrm{MSW}_{T}$ total MSW generated (tonnes), $\mathrm{MSW}_{F}$ fraction of MSW disposed of to landfills, MCF methane correction factor, DOC fraction of degradable organic carbon, $\mathrm{DOC}_{F}$ fraction of total DOC that actually degrades, $F$ fraction of methane in LFG.

The default values (0.4-1.0) for MCF are dependent on the types of MSW landfill practices. If most of the landfills under consideration are unmanaged, a value of about 0.6 can be used.

According to IPCC, DOC ranges from 0.08 to 0.21 and is estimated from

$\mathrm{DOC}=0.4 P+0.15 K+0.3 \mathrm{~W}$,

where $P$ fraction of papers in MSW, $K$ fraction of kitchen garbage in MSW, $W$ fraction of woods/leaves in MSW.

Furthermore, the $\mathrm{DOC}_{F}$ should be considered because the biodegradation of DOC does not occur totally over a long period; therefore, a default value of 0.77 can be used.

Using this to compute for Lagos,

$\mathrm{MSW}_{T}=3,380,000$ (tonnes)

$\mathrm{MSW}_{F}=0.7$ (i.e.70 \% of MSW is disposed to landfills) 
$\mathrm{MCF}=0.6$ (adopted from the Malaysian calculations given the similarities in conditions of the landfills.

$\mathrm{DOC}=0.18$ (from waste characterization by weight, $P, K$, and $V=6,4$, and $50 \%$ respectively)

$\mathrm{DOC}_{F}=0.77$ (default)

$$
F=0.5
$$

Substituting:

$\mathrm{CH}_{4}$ emissions $($ tonnes $)=130,843$ tonnes per year

$=358.47$ tonnes per day

From (34),

289.5 tonnes $\mathrm{CH}_{4} \rightarrow 73.82 \mathrm{MW}$ of electrical power

1 tonne $\mathrm{CH}_{4} \rightarrow 0.255 \mathrm{MW}$ of electrical power

$\therefore 358.47$ tonne $\mathrm{CH}_{4} \rightarrow 91.41 \mathrm{MW}$ of electrical power

(Note that this is the estimated electrical power that can be generated from a gas engine of $30 \%$ efficiency.

$\therefore P_{\mathrm{gp}}=304.7 \mathrm{MW}$ )

Breakdown:

Olusosun $=49.36 \mathrm{MW}$

Soluos $2=15.54 \mathrm{MW}$

Soluos $3=16.45 \mathrm{MW}$

Ewu-Elepe $=6.40 \mathrm{MW}$.

\section{Model 5: (IEA 2008 turning liability into asset [20])}

Correlations with estimations from actual methane production sites in Asia with the Lagos scenario gave the following results:

(a) In South Korea, small clean development mechanism (CDM) projects that generate electricity produce around 1-2 MW of electricity, while the largest handling 19,000 tonnes of MSW per day generates up to $50 \mathrm{MW}$. This can be represented as

19,000 tonnes of $\mathrm{MSW} \rightarrow 50 \mathrm{MW}$

$\therefore$ Lagos 13, 230 tonnes $\mathrm{MSW} \rightarrow 34.82 \mathrm{MW}$.

Breakdown:

Olusosun $=18.8 \mathrm{MW}$

Soluos 25.9 MW

Soluos $3=6.3 \mathrm{MW}$

Ewu-Elepe $=2.4 \mathrm{MW}$. (b) In China, the biggest LFG CDM project is in Guangzhou. It is estimated to process 6800 tonnes of MSW a day and produce up to $19 \mathrm{MW}$ of electricity capacity, avoiding almost one million tonnes of $\mathrm{CO}_{2}$ eq per year. This can be represented as

6800 tonnes of MSW $\rightarrow 19$ MW

$\therefore$ in Lagos, 13, 230 tonnes MSW $\rightarrow 36.97 \mathrm{MW}$.

Breakdown:

Olusosun $=20 \mathrm{MW}$

Soluos $2=6.3 \mathrm{MW}$

Soluos $3=6.7 \mathrm{MW}$

Ewu-Elepe $=2.6 \mathrm{MW}$.

\section{Model 5b (clean development mechanism (CDM) projects in Brazil [21])}

The Bandeirantes and Sao Joao Landfills are two CDM projects in Sao Paulo, Brazil. These landfill projects were approved as United Nations Clean Development Mechanism (CDM) projects, making Sao Paulo one of the cities to benefit from the carbon finance concept, normally reserved for the national level [22].

The Bandeirantes Landfill located along Bandeirantes Road km 26, in Perus, (Sao Paulo, Brazil) operated for 28 years, from 1979 to 2007 (currently used only for methane capture). With an area of 150 hectares/Maximum height: $100 \mathrm{~m}$, it has a waste storage of 5 million tonnes. It was estimated that about 7500 tonnes of MSW yielded close to $20 \mathrm{MW}$ of electricity. Thus,

7500 tonnes of $\mathrm{MSW} \rightarrow 20 \mathrm{MW}$

$\therefore$ Lagos : 13, 230 tonnes MSW $\rightarrow 35.33 \mathrm{MW}$.

Breakdown:

Olusosun $=19.1 \mathrm{MW}$

Soluos $2=6.0 \mathrm{MW}$

Soluos $3=6.4 \mathrm{MW}$

Ewu-Elepe $=2.5 \mathrm{MW}$.

(b) The Sao Joao Landfill located along Sapopemba Road km 33, Sao Mateus was used as a landfill from 1992 to 2009. It has an area of 80 hectares and a maximum height of garbage of $150 \mathrm{~m}$ and a waste storage of 26 million tonnes. It was estimated that about 5479 tonnes of MSW generated almost $20 \mathrm{MW}$ of electricity. Thus,

5479 tonnes of $\mathrm{MSW} \rightarrow 20 \mathrm{MW}$

$\therefore$ Lagos : 13,230 tonnes MSW $\rightarrow 48.36 \mathrm{MW}$. 


\section{Breakdown:}

$$
\begin{aligned}
\text { Olusosun } & =26.1 \mathrm{MW} \\
\text { Soluos } 2 & =8.2 \mathrm{MW} \\
\text { Soluos } 3 & =8.7 \mathrm{MW} \\
\text { Ewu-Elepe } & =3.4 \mathrm{MW} .
\end{aligned}
$$

\section{Model 6: stoichiometry}

The composite molecular formulae of the biodegradable component of the Lagos MSW can be given as

Mixed food and green wastes : $\mathrm{C}_{6} \mathrm{H}_{9.6} \mathrm{O}_{3.5} \mathrm{~N}_{0.28} \mathrm{~S}_{0.2}$

Mixed paper: $\mathrm{C}_{6} \mathrm{H}_{9.6} \mathrm{O}_{4.6} \mathrm{~N}_{0.036} \mathrm{~S}_{0.01}$.

Excluding nitrogen and sulphur, from (63) and (64) gives cellulose:

$\left(\mathrm{C}_{6} \mathrm{H}_{10} \mathrm{O}_{5}\right)_{x}$

Furthermore, the exclusion of the minor elements from (65) gives

Adipic acid:

$\mathrm{C}_{6} \mathrm{H}_{10} \mathrm{O}_{4}$.

Fundamentally, the production of LFG follows the order:

$\mathrm{C}_{6} \mathrm{H}_{10} \mathrm{O}_{4}+1.5 \mathrm{H}_{2} \mathrm{O}=3.25 \mathrm{CH}_{4}+2.75 \mathrm{CO}_{2}$

adipic acid (waste).

Given:

$417 \mathrm{~kg}$ of adipic acid (a dicarboxylic acid $\left(\mathrm{CH}_{2}\right)_{4}$ $(\mathrm{COOH})_{2}$ also called hexane-1,6, dioic acid) comes from I tonne of MSW.

Thus, in the Lagos landfills,

1 tonne $\mathrm{MSW} \rightarrow 0.6$ tonne biomass

$$
\rightarrow 0.417 \text { tonne } \mathrm{C}_{6} \mathrm{H}_{10} \mathrm{O}_{4} \rightarrow x \text { tonne } \mathrm{CH}_{4}
$$

[from (68), about $69.5 \%$ of the biomass is adipic acid]. From (67),

$$
\begin{aligned}
& 146 \mathrm{~kg} \mathrm{C}_{6} \mathrm{H}_{10} \mathrm{O}_{4} \rightarrow(3.25 \times 16) \mathrm{kg} \mathrm{CH}_{4} \\
& \therefore 417 \mathrm{~kg} \mathrm{C}_{6} \mathrm{H}_{10} \mathrm{O}_{4} \rightarrow 149 \mathrm{~kg} \mathrm{CH}_{4}
\end{aligned}
$$

Equation (68) can be re-written as

1 tonne $\mathrm{MSW} \rightarrow 0.6$ tonne biomass

$$
\begin{aligned}
& \rightarrow 0.417 \text { tonne } \mathrm{C}_{6} \mathrm{H}_{10} \mathrm{O}_{4} \\
& \rightarrow 0.149 \text { tonne } \mathrm{CH}_{4} .
\end{aligned}
$$

Similarly,

1 tonne biomass $\rightarrow 0.695$ tonne $\mathrm{C}_{6} \mathrm{H}_{10} \mathrm{O}_{4}$

$$
\rightarrow 0.2483 \text { tonne } \mathrm{CH}_{4}
$$

1 tonne $\mathrm{C}_{6} \mathrm{H}_{10} \mathrm{O}_{4} \rightarrow 0.3573$ tonne $\mathrm{CH}_{4}$.

Note that,

Molar weight (MW) of $\mathrm{C}_{6} \mathrm{H}_{10} \mathrm{O}_{4}$

$=146, \therefore 146 \mathrm{~kg} \mathrm{C}_{6} \mathrm{H}_{10} \mathrm{O}_{4} \rightarrow 1 \mathrm{Kmol} \mathrm{C}_{6} \mathrm{H}_{10} \mathrm{O}_{4}$

$\mathrm{MW}$ of $\mathrm{CH}_{4}=16, \therefore 16 \mathrm{~kg} \mathrm{CH}_{4} \rightarrow 1 \mathrm{Kmol} \mathrm{CH}_{4}$.

From Gas laws, $1 \mathrm{kmol}$ of any chemical substance occupies $22.4 \mathrm{Nm}^{3}$ at STP.

$16 \mathrm{~kg} \mathrm{CH}_{4} \rightarrow 1 \mathrm{Kmol} \mathrm{CH}_{4} \rightarrow 22.4 \mathrm{Nm}^{3}$

$1 \mathrm{~kg} \mathrm{CH}_{4} 1.4 \mathrm{Nm}^{3} \mathrm{CH}_{4}$

1tonne $\mathrm{CH}_{4} \rightarrow 1400 \mathrm{Nm}^{3} \mathrm{CH}_{4}$

0.149 tonne $\mathrm{CH}_{4} \rightarrow 208.6 \mathrm{Nm}^{3} \mathrm{CH}_{4}$

Equation (71) can be modified to give

$$
\begin{aligned}
1 \text { ton } \mathrm{MSW} & \rightarrow 0.417 \text { ton } \mathrm{C}_{6} \mathrm{H}_{10} \mathrm{O}_{4} \rightarrow 0.149 \text { ton } \mathrm{CH}_{4} \\
& \rightarrow 208.6 \mathrm{Nm}^{3} \mathrm{CH}_{4} .
\end{aligned}
$$

Corollary, the following were also considered:

(a) In 2006, Themelis and Ulloa [23] gave the following theoretical estimation for methane generation from MSW in USA:

2,600,000 tonnes $\mathrm{CH}_{4} \rightarrow 3,700,000,000 \mathrm{Nm}^{3} \mathrm{CH}_{4}$

Thus

1 tonne $\mathrm{CH}_{4} \rightarrow 1423 \mathrm{Nm}^{3} \mathrm{CH}_{4}$.

(b) Yip [24] in Malaysia estimated that

1 tonne $\mathrm{CH}_{4} \rightarrow 1000 \mathrm{~m}^{3} \mathrm{CH}_{4}$

$\left(c_{1}\right)$ However in practice, Themelis and Ulloa [23] observed in many of the US landfills that

1 tonne $\mathrm{MSW} \rightarrow 100 \mathrm{Nm}^{3} \mathrm{CH}_{4}$ [i.e. about $48 \%$ of theoretical 208.6 in (75e) and (76a)]

$\left(c_{2}\right)$ Similarly, Surroop and Mohee [16] estimated that

1 tonne MSW $\rightarrow 122 \mathrm{~m}^{3} \mathrm{CH}_{4}$ where methane is $50 \%$ LFG [about $58.6 \%$ of theoretical (76a), if same as normal condition]

(d) Using US EPA LandGEM Ecuador [25]

1 ton $\mathrm{MSW} \rightarrow 84 \mathrm{Nm}^{3} \mathrm{CH}_{4}$ ( about $40 \%$ of theoretical)

Thus, Themelis and Ulloa [23] proposed the conservative estimate below

1 ton $\mathrm{MSW} \rightarrow 50 \mathrm{Nm}^{3} \mathrm{CH}_{4}$ (about $24 \%$ of theoretical).

The methane generation capacity of MSW of the world per year can thus be estimated: 
Population of the world $\rightarrow 7,000,000,000$

Generation per capita GPC $\rightarrow 0.214$ ton/year (i.e. about $0.586 \mathrm{~kg} / \mathrm{day})$.

Global MSW per year $\rightarrow 1.498$ billion tonnes

Global methane generation from MSW/year

$\rightarrow 74.9$ billion $\mathrm{Nm}^{3} \mathrm{CH}_{4}$

It may be noted that only about $10 \%$ of (79) is currently being captured.

Using (78), in Lagos,

9261 tonnes $\mathrm{MSW} \rightarrow 463,050 \mathrm{Nm}^{3} /$ day $\mathrm{CH}_{4}$

9261 tonnes $\mathrm{MSW} \rightarrow 19,293.8 \mathrm{Nm}^{3} / \mathrm{h} \mathrm{CH}_{4}$.

Recall from (22-25a): 1,132,056 $\mathrm{m}^{3} /$ day $\mathrm{CH}_{4} \rightarrow 47,169 \mathrm{~m}^{3} / \mathrm{h} \mathrm{CH}_{4} \rightarrow 72.53 \mathrm{MW}$.

Thus from (80-81), the most conservative electricity from stoichiometry is:

$463,050 \mathrm{~m}^{3} \mathrm{CH}_{4} \rightarrow 19,293.8 \mathrm{~m}^{3} / \mathrm{h} \mathrm{CH}_{4} \rightarrow 29.7 \mathrm{MW}$

(Since, this is only about $24 \%$ of the theoretical (from stoichiometry), it means that assuming a $100 \%$ utilisation as depicted by the chemical equation, the derivable electricity from a similar combustion engine of $30 \%$ efficiency would be about $123.75 \mathrm{MW}$ ).

\section{Model 7: US EPA LandGEM Ecuador [25]—based on first order decay equation}

Most available global models which predict biogas from landfills are among the ones developed based on first order decay models. These models consider quality of waste (i.e. moisture content, carbon content, age of waste and ability of waste to be digested), waste quantity and condition of landfill (i.e. climate, temperature, precipitation) implicitly. In the order words, the effect of depletion of carbon in the waste through time is accounted for in a first-order model [26]. In this work, the USEPA developed software: Ecuador Landfill Gas Model Version 1.0 (2009) was used. The results are shown in Fig. 5. It is hinged on the formula given below:

$\mathrm{QCH}_{4}=\sum_{i=1}^{n} \sum_{j=0.1}^{1} k L_{o}\left[\frac{M_{i}}{10}\right] \mathrm{e}^{-k t_{i j}}$,

where $\mathrm{QCH}_{4}$ annual methane generation for a specific year $t\left(\mathrm{~m}^{3} \mathrm{CH}_{4} /\right.$ year $), i 1$ year time increment, $n$ year of the calculation or initial year of waste acceptance), $j$ the deciyear time increment (i.e. 0.1 year time increment), $k 1$ st order decay rate constant (1/year) (also known as methane generation rate), $L_{0}$ total methane generation potential
( $\mathrm{m}^{3} \mathrm{CH}_{4} /$ ton of waste), $M_{i}$ the annual burial rate (wet tons) (i.e. mass of waste accepted in the $j$ th year in tonne.), $t_{i j}$ time after initial waste placement (year) (also known as the age of the $j$ th section of the waste mass $M_{i}$ accepted in the $j$ th year (decimal years, e.g. 3.2 years).

Estimations of the landfill gas potentials using various practical data and scholarly postulations for the Lagos area with a human population of about 21,000,000; showed some level of disparities and ambiguities amongst the various theoretical derivations. This is understandable in that different factors were used in their derivations. From stoichiometry, the derivable electricity from the Lagos MSW is estimated at about $123.75 \mathrm{MW}$. By comparing with the evaluations made using different models and equations by some authors in other parts of the world, a mean electricity value of $99.33 \mathrm{MW}$ was projected.

In a general context, it is known that discharge of greenhouse gases (GHGs) and the management of municipal solid waste (MSW) continue to be a major challenge particularly in growing economies. However, these are resources which can be converted to green energy [27]. Landfill gas is continuously generated due to the anaerobic degradation of the organic fraction of solid waste. Therefore, in a landfill in which an extracting system is not installed, there will be an over-pressure that will force the biogas to be released into the atmosphere [16]. The outbreak of fire in the Lagos landfills is a recurring decimal.

Methane has 23 times the globe warming potential of carbon dioxide [28]. An estimated $12 \%$ of methane emissions are caused by landfilling of wastes [2]. This is quite significant given that about 1.5 billion tonnes of methane is produced from landfills across the world annually, with only about $10 \%$ of this being captured [1]. Therefore, a study of this nature which seeks to accurately estimate the green energy potential of Lagos in tandem with practicality is quite important (Fig. 6).

\section{Conclusion}

Apart from the Epe landfill, all the landfills in Lagos are underlain by attenuative and compacted soils which can serve as seals and prevent further migration of landfill gases thereby enhancing their beneficiation potentials upon proper capping.

One area where LFG capture estimation for electricity is critical is in terms of its economics. This explains why a number of veritable options were used in this work to aid in this estimation. Model 1 presents a simplistic outlook which considers just the mass and the calorific value of MSW. Therefore, the resultant estimation of $121.83 \mathrm{MW}$ 

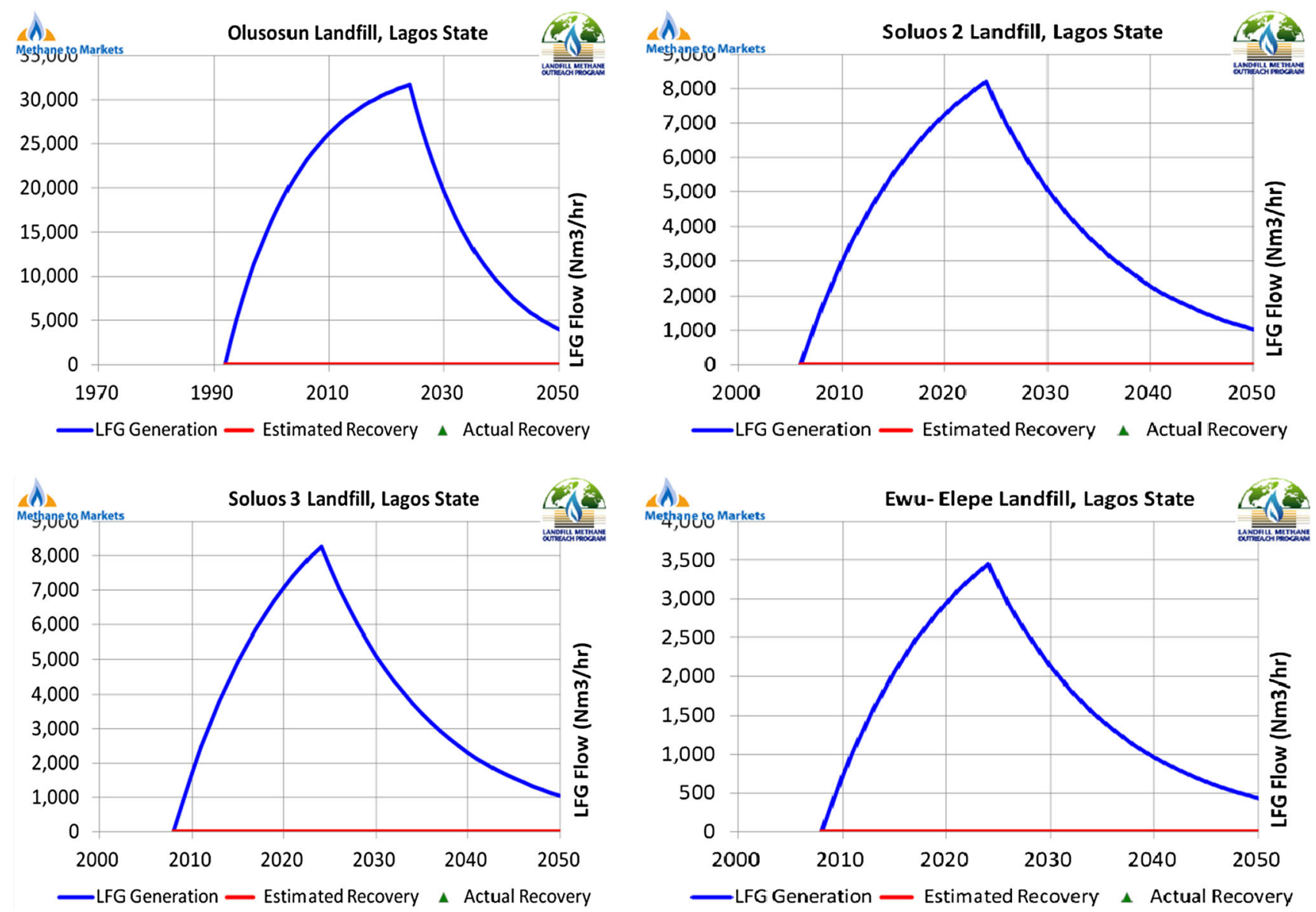

Fig. 5 Methane generation potential of the various landfills in Lagos

Fig. 6 Estimation of LFG electricity (a based on comparison with various theories; $\mathbf{b}$ based on comparison with field data)

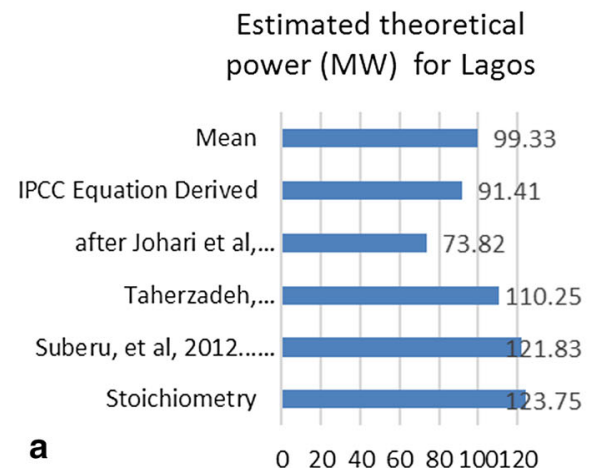

presents a rough guide. Model 2's value of 110.25 MW stems also from a rough estimate of what is achievable using just anaerobic degradation. The result of 36,265 MW in Model 3 ensues from correlation with field data in Mauritius. This model applies gas laws and the properties of methane such as its density and lower heating value. It also considers the gas flow rate and engine efficiency of the capture facility. It is perhaps the closest approximation in reality. Model 4a's estimate of 73 . $82 \mathrm{MW}$ is hinged on stoichiometry and this considers the biomass which is the power house for anaerobic LFG generation. By using Model $4 \mathrm{~b}$, attention was drawn to what could be derivable using a number of hypothetical values as default values. Amongst other things, this model does not consider waste age or type. Therefore, it is understandable why its derived value of 91.4 MW only 
provides a clue in evaluation. Correlations with The International Energy Agency (Model 5) values (from field data in South Korea, China and Bandeirantes in Brazil) hover between 34 . 82-36.97 MW with a mean of 35.54 MW. This value of 35.54 MW approximates closely with the figure of $36.265 \mathrm{MW}$ deduced by comparison with field data in Mauritius and proves the efficacy of the proper use of actual data. Nonetheless, theoretical data cannot be dismissed for show of disparity in values. For instance, from stoichiometry, it is reported in this work that the maximum derivable electricity from LFG in the Lagos area (from current data) is about $123.75 \mathrm{MW}$. This means that any value beyond this figure is theoretically impossible. It also means that only a fraction of this value can be obtained. For one, it is often not possible for all the theoretically possible methane to be formed within the landfill. Also, it is not guaranteed that all the available methane can be harnessed by the LFG capture facility. These limitations are proven by existing field data.

Using the lower limits of conservative empirical observations in some LFG capture sites in the US, South Korea, Brazil, Mauritius and China; an estimated mean electrical power of $38.35 \mathrm{MW}$ - capable of providing electricity to over 230,000 inhabitants was deduced. This represents about $31 \%$ of values obtained theoretically via stoichiometry and indicates that only about a third of the theoretical landfill electricity potential is achievable with existing technology. This conservative evaluation based on actuality, may aid to eradicate spurious estimations for practical purposes and is critical in terms of global LFG capture economics. The concomitant benefits upon exploitation are expected to be exponentially higher in terms of reduction of greenhouse gases and mitigation of environmental hazards.

Authors' Contribution IIM conceptualized the problem, plausible pathways for resolution and drafted the manuscript. CAN supervised and approved the draft. Both authors read and approved the final manuscript.

Acknowledgments The authors are profoundly grateful to the Managing Director of LAWMA: Mr. Ola Oresanya and his able crew for the immense co-operation enjoyed all through the geological site investigation of this work. The immense and uncommon assistance provided by John Amadin and his family will remain evergreen.

Conflict of interest The authors declare that there is no competing interest.

Open Access This article is distributed under the terms of the Creative Commons Attribution 4.0 International License (http:// creativecommons.org/licenses/by/4.0/), which permits unrestricted use, distribution, and reproduction in any medium, provided you give appropriate credit to the original author(s) and the source, provide a link to the Creative Commons license, and indicate if changes were made.

\section{References}

1. Idehai I.M.: Municipal Solid Waste Disposal in Lagos: Effects on the Environment, and Partial Estimation of the Landfill Gas and Recyclable Potentials. M.Sc thesis, University of Benin, Nigeria (2013)

2. Ahmed, S.I., Johari, A., Hashim, H., Ramli, M., Alkali, H.: Landfill gas and its renewable energy potentials in johor, Malaysia. Int. J. Emerg. Trends Eng. Dev. 3, 15 (2013)

3. Akujieze, C.N., Idehai, I.M.: Standardization of the electricity and economic potentials of landfill gas (LFG) in Lagos, Nigeria. Int. J. Sci. Eng. 7(1), 1-9 (2014). doi:10.12777/ijse.7.1.1-9

4. Suberu, M.Y., Mokhtar, A.S., Bashir, N.: Renewable power generation opportunity from municipal solid waste: a case study of Lagos metropolis (Nigeria). J. Energy Technol. Policy 2(2), 15 (2012). ISSN 2224-3232

5. Tattam, C.M.: A review of Nigerian stratigraphy, pp. 27-46. Geol. Surv. Niger. Rep., Lagos (1943)

6. Jones, H.A., Hockey, R.D.: The geology of part of S. W. Nigeria. Geol. Surv. Niger. Bull 31, 87 (1964)

7. Lavalin: Organizational development and waste management system project. Design and Operations Report for the Oregun Landfill Site Submitted to the Lagos State Waste Disposal Board, p 120 (1992)

8. Bhide, A.D.: Methane emission from landfills. J. 1AEM 21, 1-7 (1994)

9. Longe, E.O., Malomo, S., Olorunnwo, M.A.: Hydrogeology of Lagos metropolis. J. Afr. Earth Sci. 6(2), 163-174 (1987)

10. Landfill Recovery and use in Nigeria (Pre-feasibility Studies of using LFGE) Final Report (2010). https://www.globalmethane. org/Data/347_Landfill.Recovery.and.Use.in.Nigeria(LFGE)Final. Report.pdf. Accessed 14th April 2015

11. Punch Newspaper Nigeria: Power Generation Drops by 1074 MW (April 10th, 2013). http://www.punchng.com/news/ power-generation-drops-by-1074mw/. Accessed 14th April 2015

12. Waste Management. Landfill Gas-to-Energy: How it is Done (2006). http://www.youtube.com/watch?v=w1RKMMpRRHY. Accessed 9th February 2014

13. LAWMA: Sustainable solid waste management in developing countries: lagos as a case study. In: LAWMA, pp. 111 (2011). http://www.lawma.gov.ng. Accessed 14th April 2015

14. United Nations Population Fund, UNFPA. The State of World Population Chapter 3: Development Levels and Environmental Impact, p. 19 (2001). https://www.unfpa.org/swp/2001/english/ ch03.html. Accessed 14th March 2014

15. Taherzadeh, M.J.: Waste to wealth. Vetensk. Prof. 10(73-38), 6 (2009)

16. Surroop, D., Mohee, R.: power generation from landfill gas. In: 2nd International Conference on Environmental Engineering and Applications IPCBEE, vol. 17, p. 8. IACSIT Press, Singapore (2011)

17. Johari, A., Ahmed, S.I., Hashim, H., Alkali, H., Ramli, M.: Economic and environmental benefits of landfill gas from municipal solid waste in Malaysia. Renew. Sustain. Energy Rev. 16(2907-2912), 6 (2012)

18. Kamalan, H., Sabour, M., Shariatmadari, N.: A review on available landfill gas models. J. Environ. Sci. Technol. 4, 79-92 (2011)

19. Inter-governmental Panel on Climate Change, IPCC: revised ipcc guidelines for national greenhouse gas inventories: reference manual. In: Houghton, J.T., Meira Filho, L.G., Lim, B., Treanton, K., Mamaty, I., Bonduki, Y., Bacallender D. (eds.) IPCC/OECD/ IEA. UK Meteorological Office, Bracknell (1996)

20. IEA: Energy Technology Perspective, OECD/IEA, Paris (2008). https://www.iea.org/techno/etp/ETP_2008_Exec_Sum_English. pdf. Accessed 9th February 2014 
21. CDM Projects: http://www.mct.gov.br/clima. Accessed 14th April 2015

22. NYC Global Partners' Innovation Exchange: Best Practice: Landfill Emissions Control (2012). http://www.nyc.gov/glo balpartners/innovationexchange. Accessed 14th April 2015

23. Themelis, N.J., Ulloa, P.A.: Methane generation in landfill. Renew. Energy 32, 1243-1257 (2006)

24. Yip, C.H., Chua, K.H.: An overview on the feasibility of harvesting landfill gas from MSW to recover energy. ICCBT F 28 , 303-310 (2008)

25. US EPA LandGEM Ecuador Version 1.0 (2009). http://www.epa. gov/lmop/international/tools.html\#a03. Accessed 9th February 2014

26. Ozakaya, B., Demir, A., Bilgili, M.B.: Neural network prediction model for the methane fraction in biogas from field-scale landfill bioreactors. Environ. Model. Softw. 22, 815-822 (2006)

27. Yedla, S., Parikh, I.K.: Economic evaluation of a landfill system with gas recovery for municipal solid waste management: a case study. Int. J. Environ. Pollut. 15(4), 433-447 (2001)
28. Intergovernmental Panel on Climate Change, IPCC. 2013 Report. http://www.climatechange2013.org/images/report/WG1AR5_AL L_FINAL.pdf. Accessed 15th March 2014

Imoukhuede Moses Idehai is an environmental researcher with professional experience spanning over a decade and a half. $\mathrm{He}$ is a chartered geologist and member of various professional societies including the Nigeria Mining and Geosciences Society (NMGS), and the Geological Society of America (GSA). An avid writer, his published articles can be found in various reputable national and international journals.

Christopher N. Akujieze is of the Department of Geology, University of Benin (Nigeria). A Fulbright scholar, his numerous environmentally related publications have received rave reviews and critical acclaims from pundits across the globe. 